\title{
Do Factor Shares Reflect Technology?
}

\author{
Benjamin Bental* \\ Dominique Demougin**
}

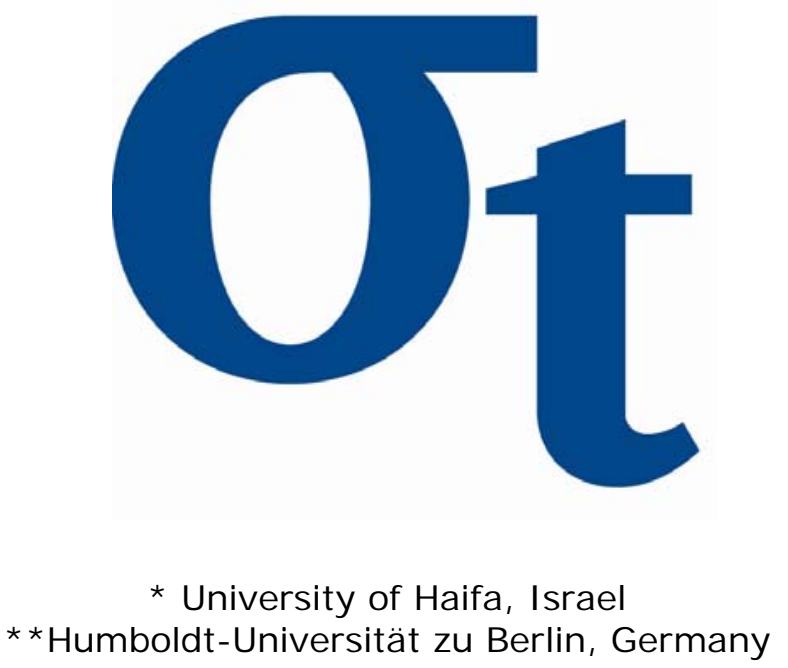

This research was supported by the Deutsche Forschungsgemeinschaft through the SFB 649 "Economic Risk". 


\title{
Do Factor Shares Reflect Technology?
}

\author{
Benjamin Bental*and Dominique Demougin ${ }^{\dagger \ddagger}$
}

September 2005

\begin{abstract}
This note demonstrates that it is easily possible to compute technological parameters out of national income accounting data in the presence of bargaining in the labor market. Applying the method to US data, we obtain that the output elasticity with respect to capital exceed 0.5.

[JEL. E23, E25]

KEYWORdS: FACTOR SHARES, NASH BARGAINING
\end{abstract}

\section{Introduction}

In many macro models, it is standard to associate labor and capital shares of national income with technological parameters of the aggregate production function. In particular, in the Cobb-Douglas formulation, these shares are simply the respective exponents of capital and labor. Since the labor share in national income is approximately $70 \%$ in most industrialized nations, it is common to use an exponent of about 0.3 for capital in such a formulation. This association is, of course, based on the assumption that factors are paid their respective marginal products. However, the labor share that emerges from direct estimates of aggregate production functions under the competitive pricing mechanism, tends to be significantly

*University of Haifa, Haifa Israel. E-mail bbental@econ.haifa.ac.il

${ }^{\dagger}$ Humboldt University at Berlin, Berlin Germany. E-mail: ddemoug@wiwi.hu-berlin.de

${ }^{\ddagger}$ We are thankful to the DFG for financial support through the SFB 649 . 
lower than the above $70 \%$. For example, the production function estimates of Duffy and Papageorgiou, 2000, imply that labor shares in the developed countries cannot exceed 0.32 under competitive factor markets. This is, of course, the share usually associated with capital. ${ }^{4}$

We show that a model that includes the bargaining feature can reconcile the technological parameters with the factor shares as they are observed. Specifically, we replace the competitive market mechanism of wage determination with a Nash bargaining process as is commonly done in the labor literature (e.g. see Pissarides (2000) and the literature therein), and show that technological parameters can still be extracted from the national income accounts. Not surprisingly however, these will reflect bargaining power and, in general, differ from the factor shares. ${ }^{5}$

\section{The Model}

We consider a small open economy populated by identical workers on a continuum of measure 1. Potential firms are drawn from the real line. Firms own a production technology that employs capital and one unit of labor where both inputs are essential. ${ }^{6}$ Let $f(k)$ denote the output per worker, where $k$ represents capital per worker, and assume that $f(k)$ satisfies the Inada conditions. Firms pay a firm

\footnotetext{
${ }^{4}$ Duffy and Papageorgiou estimate a production function of the form $Y=A\left[\delta K^{-\rho}+(1-\right.$ $\left.\delta) L^{-\rho}\right]^{-\frac{1}{\rho}}$. For this specification, the labor share is $\frac{(1-\delta) k^{\rho}}{\delta+(1-\delta) k^{\rho}}$, where $k$ is the capital labor ratio. The implication follows from the parameter values estimated for developed countries, $\rho=-0.08$ (with marginal significance) and $\delta=0.68$ (highly significant, see Table 3 , page 109).

${ }^{5}$ We are not the first to observe that bargaining may cause deviations from marginal value of product pricing. For example, Bentolila and Saint-Paul (2003), as well as Blanchard (2004) invoke bargaining power as one of the explaining factors for movements in labor shares in Europe (see also Spector, 2004).

${ }^{6}$ For parsimony, we assume that every firm can employ at most one worker. One could relax the requirement as long as there is an upper bound on the number of workers a firm can hire.
} 
specific setup cost of $z(i)$ units of unmeasured effort and time upon entering the market where $i$ indexes the firm. ${ }^{7}$ Without loss of generality, we order the potential entrants according to their setup costs in an ascending order, i.e. $z^{\prime}(i)>0$. Moreover, we assume $z(0)=0$ and $z^{\prime \prime}>0 .^{8}$

The sequence of events is as follows. Upon entering each firm pays the setup costs. Next, it hires capital at a given rental rate $r$ (which includes depreciation allowance). Third, firms are matched with workers. For parsimony, we assume that every worker is matched with a firm, but not vice et versa. We denote by $p$ the fraction of firms that are matched. This fraction is taken as given from the point of view of potential entrants, but is determined in the aggregate by the measure of firms that enter.

Concerning the modelling strategy, three remarks are in order. First, we introduce increasing setup costs in order to limit entry. Specifically, the marginal entrant will have zero profits. Second, the sequence of events is different from the usual one in the MP literature. In particular, firms invest in capital before they hire labor which generates a hold up problem at the later wage negotiations stage. $^{9}$ Third, the matching technology reconciles the zero profit condition of the marginal entrant with the deviation from the competitive wage determination mechanism presented below. More general matching technologies, where not all workers are matched, would also work, as long as $p$ remains decreasing in the measure of entering firms.

\footnotetext{
${ }^{7}$ Our notion of umeasured effort can be interpreted in the spirit of McGrattan and Prescott (2005), who have recently suggested that there is a sizable amount of "sweat equity" that does not get measured by NIPA.

${ }^{8}$ The essential feature is that setup costs increase with the number of firms.

${ }^{9}$ A notable exception is Acemoglu and Shimer (1999).
} 
We solve the model by backward induction. We start in the third stage. In the case of a match between a worker and a firm, the two parties bargain over the quasi-rent. We assume that the outcome of the bargaining process can be represented by the Nash-bargaining solution where the respective disagreement points are zero. We parametrize the bargaining power of labor by $\alpha$, which we assume to be exogenously given. ${ }^{10}$ Since at the bargaining stage the capital/labor ratio, $k$, is given, the bargaining problem between a firm and its worker amounts to solving

$$
\max _{w}[f(k)-w]^{1-\alpha} w^{\alpha}
$$

Accordingly, the worker is paid a fixed proportion of output:

$$
w=\alpha f(k) .
$$

Moving back to the second stage of the game, firms that have entered decide on the capital/labor ratio anticipating the expected outcome of the matching and bargaining stage. The problem of the firm is:

$$
\pi=\max _{k} p(1-\alpha) f(k)-r k
$$

implying the following decision rule for capital:

$$
p(1-\alpha) f^{\prime}(k)-r=0
$$

\footnotetext{
${ }^{10}$ This parameter is thought to represent inter alia, legal institutions governing wage setting and work conditions.
} 
In the first stage firm $i$ enters if

$$
\pi-z(i) \geq 0
$$

Definition 2.1. An equilibrium is a vector $\left(p^{*}, i^{*}, k^{*}, w^{*}, \pi^{*}\right)$ satisfying the following conditions:

At the firm level:

i) The solution to the Nash-bargaining problem form (2.2).

ii) The capital optimization condition (2.4).

iii) The entry decision from (2.3) and (2.5).

At the aggregate level:

iv) Zero profit determining the marginal entrant, $\iota^{*}$.

v) The probability of a match $p^{*}=1 / i^{*}$.

Given the Inada condition, it is easily verified that an equilibrium exists as long as $z(1)$ is not too large. ${ }^{11}$ Thus, we have shown that the above game is consistent with profit maximizing, zero profit condition for the marginal entrant, and the deviation from the competitive wage determination mechanism described above.

\section{Factor shares and technology parameters}

In our model, the labor share is simply $\alpha$. In particular, it does not reflect any technological parameters, thus, no contradiction between implied factor shares

\footnotetext{
${ }^{11}$ This condition simply guarantee that at $i=1$ firms are still attracted to the market. Otherwise, the model is not consistant with the assumption that every worker is matched.
} 
and technology can arise. Nevertheless, we show next that it is still possible to elicit technology parameters from standard macro-data.

To do so, we proceed by using the Cobb-Douglas specification so that $f(k)=$ $k^{\gamma}$. Using (2.2) and (2.4), we get:

$$
\gamma=\frac{r \frac{k}{y}}{p\left[1-\frac{w}{y}\right]}
$$

where $y=f(k)$.

We apply this result to the corporate sector in the US. This is done in order to isolate capital from other types of assets such as residential and government capital. We use the computations of McGrattan and Prescott (2000). They report (in table 1) that the corporate sector was responsible in the period 1990-1999 for $59.2 \%$ of GNP. The capital GNP ratio of that sector amounted to 0.821. Accordingly, the capital output ratio in the corporate sector amounts to 1.38. Next, we compute $r$ using the capital consumption (6.9\% of GDP) and net interest payments (1.5\% of GDP), thus, $r=14.2 \%$. We compute $\alpha$ from labor compensation (37.8\% of GDP) to be 0.63 . Finally, using an average vacancy rate of $2.7 \%$ from the BLS, we set $p=0.973 .{ }^{12}$ Altogether, we obtain $\gamma=0.54$.

Furthermore, the model allows us to compute for profit in the economy. To do so, we interpret the $i z(i)$ as the sum of profit. Specifically, we assume that the entry costs, $z(\cdot)$, are not reflected by the NIPA and therefore all reported profits are gross of the entry cost. Accordingly, total profits in the economy amount to:

\footnotetext{
${ }^{12}$ For the data, see Job Openings and Labor Turnover Survey at http://data.bls.gov/cgibin/surveymost.
} 


$$
\int_{0}^{i} \pi(z) d z=(1-\alpha) f(k)-i r k
$$

Simple manipulations show that the share of profit out of output is $(1-\alpha)(1-\gamma)$. Using the above numbers this share amounts to 17\%. In McGrattan and Prescott, (2000), the corporate profit to GNP ratio is 0.093. Therefore, in the data we get the share of profit out of corporate output to be $15.7 \% .^{13}$

\section{Concluding remarks}

Clearly a higher value of $\gamma$ reduces the contribution to growth attributed to total factor productivity. As a matter of fact, high values of $\gamma$ have already been invoked by Romer (1986) and Bental and Peled (1996) in order to explain growth phenomena. We have shown that introducing bargaining into a standard macroeconomic model may help justify such estimates.

\footnotetext{
${ }^{13}$ Observe that we did not take indirect business taxes of $5.7 \%$ of GNP into account.
} 


\section{References}

Acemoglu, Daron and Robert Shimer (1999): "Holdups and Efficiency with Search Frictions", International Economic Review (40), pp. 827-850.

Bental, Benjamin and Dan Peled (1996): "The accumulation of wealth and the cyclical generation of new technologies: A Search Theoretic Approach", International Economic Review 37, pp. 687-718.

Blanchard, Olivier (2004): "The Economic future of Europe", M.I.T. Working Paper 04-04.

Bentolila, Samuel and Gilles Saint-Paul (2003): "Explaining Movements in the Labor Share", Contributions to Macroeconomics, http://www.bepress.com/bejm/ contributions/vol3/iss1/art9

Duffy, John and Chris Papageorgiou (2000): "A Cross-Country Empirical Investigation of the Aggregate Production Function Specification", Journal of Economic Growth, 5: 87-120.

McGrattan, Ellen R. and Edward C. Prescott (2000): "Is the stock market overvalued?," Quarterly Review, Federal Reserve Bank of Minneapolis, issue Fall, pp. $20-40$.

McGrattan, Ellen R. and Edward C. Prescott (2005): "Sweat Equity", Federal Reserve Bank of Minneapolis, Working Paper 636.

Pissarides, Christopher (2000): Equilibrium Unemployment Theory, 2nd edition, The MIT Press.

Romer, Paul (1987): "Crazy Explanations for the Productivity Slowdown", in Stanley Fischer, ed., NBER Macroeconomics Annual, Cambridge, The MIT Press, pp. 163-201. 
Spector, David (2004): "Competition and the Capital-Labor Conflict", European Economic Review, vol. 48 (1), pp. 25-38. 


\section{SFB 649 Discussion Paper Series}

For a complete list of Discussion Papers published by the SFB 649, please visit http://sfb649.wiwi.hu-berlin.de.

001 "Nonparametric Risk Management with Generalized Hyperbolic Distributions" by Ying Chen, Wolfgang Härdle and Seok-Oh Jeong, January 2005.

002 "Selecting Comparables for the Valuation of the European Firms" by Ingolf Dittmann and Christian Weiner, February 2005.

003 "Competitive Risk Sharing Contracts with One-sided Commitment" by Dirk Krueger and Harald Uhlig, February 2005.

004 "Value-at-Risk Calculations with Time Varying Copulae" by Enzo Giacomini and Wolfgang Härdle, February 2005.

005 "An Optimal Stopping Problem in a Diffusion-type Model with Delay" by Pavel V. Gapeev and Markus Reiß, February 2005.

006 "Conditional and Dynamic Convex Risk Measures" by Kai Detlefsen and Giacomo Scandolo, February 2005.

007 "Implied Trinomial Trees" by Pavel Čížek and Karel Komorád, February 2005.

008 "Stable Distributions" by Szymon Borak, Wolfgang Härdle and Rafal Weron, February 2005.

009 "Predicting Bankruptcy with Support Vector Machines" by Wolfgang Härdle, Rouslan A. Moro and Dorothea Schäfer, February 2005.

010 "Working with the XQC" by Wolfgang Härdle and Heiko Lehmann, February 2005.

011 "FFT Based Option Pricing" by Szymon Borak, Kai Detlefsen and Wolfgang Härdle, February 2005.

012 "Common Functional Implied Volatility Analysis" by Michal Benko and Wolfgang Härdle, February 2005.

013 "Nonparametric Productivity Analysis" by Wolfgang Härdle and Seok-Oh Jeong, March 2005.

014 "Are Eastern European Countries Catching Up? Time Series Evidence for Czech Republic, Hungary, and Poland" by Ralf Brüggemann and Carsten Trenkler, March 2005.

015 "Robust Estimation of Dimension Reduction Space" by Pavel Čížek and Wolfgang Härdle, March 2005.

016 "Common Functional Component Modelling" by Alois Kneip and Michal Benko, March 2005.

017 "A Two State Model for Noise-induced Resonance in Bistable Systems with Delay" by Markus Fischer and Peter Imkeller, March 2005.

018 "Yxilon - a Modular Open-source Statistical Programming Language" by Sigbert Klinke, Uwe Ziegenhagen and Yuval Guri, March 2005.

019 "Arbitrage-free Smoothing of the Implied Volatility Surface" by Matthias R. Fengler, March 2005.

020 "A Dynamic Semiparametric Factor Model for Implied Volatility String Dynamics" by Matthias R. Fengler, Wolfgang Härdle and Enno Mammen, March 2005.

021 "Dynamics of State Price Densities" by Wolfgang Härdle and Zdeněk Hlávka, March 2005.

022 "DSFM fitting of Implied Volatility Surfaces" by Szymon Borak, Matthias R. Fengler and Wolfgang Härdle, March 2005.

\section{SFB 649, Spandauer Straße 1, D-10178 Berlin http:/ / sfb649.wiwi.hu-berlin.de}

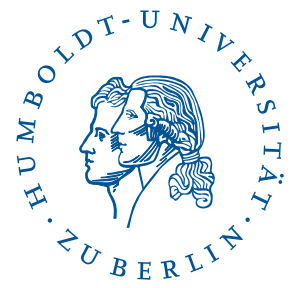


023 "Towards a Monthly Business Cycle Chronology for the Euro Area" by Emanuel Mönch and Harald Uhlig, April 2005.

024 "Modeling the FIBOR/EURIBOR Swap Term Structure: An Empirical Approach" by Oliver Blaskowitz, Helmut Herwartz and Gonzalo de Cadenas Santiago, April 2005.

025 "Duality Theory for Optimal Investments under Model Uncertainty" by Alexander Schied and Ching-Tang Wu, April 2005.

026 "Projection Pursuit For Exploratory Supervised Classification" by EunKyung Lee, Dianne Cook, Sigbert Klinke and Thomas Lumley, May 2005.

027 "Money Demand and Macroeconomic Stability Revisited" by Andreas Schabert and Christian Stoltenberg, May 2005.

028 "A Market Basket Analysis Conducted with a Multivariate Logit Model" by Yasemin Boztuğ and Lutz Hildebrandt, May 2005.

029 "Utility Duality under Additional Information: Conditional Measures versus Filtration Enlargements" by Stefan Ankirchner, May 2005.

030 "The Shannon Information of Filtrations and the Additional Logarithmic Utility of Insiders" by Stefan Ankirchner, Steffen Dereich and Peter Imkeller, May 2005.

031 "Does Temporary Agency Work Provide a Stepping Stone to Regular Employment?" by Michael Kvasnicka, May 2005.

032 "Working Time as an Investment? - The Effects of Unpaid Overtime on Wages, Promotions and Layoffs" by Silke Anger, June 2005.

033 "Notes on an Endogenous Growth Model with two Capital Stocks II: The Stochastic Case" by Dirk Bethmann, June 2005.

034 "Skill Mismatch in Equilibrium Unemployment" by Ronald Bachmann, June 2005.

035 "Uncovered Interest Rate Parity and the Expectations Hypothesis of the Term Structure: Empirical Results for the U.S. and Europe" by Ralf Brüggemann and Helmut Lütkepohl, April 2005.

036 "Getting Used to Risks: Reference Dependence and Risk Inclusion" by Astrid Matthey, May 2005.

037 "New Evidence on the Puzzles. Results from Agnostic Identification on Monetary Policy and Exchange Rates." by Almuth Scholl and Harald Uhlig, July 2005.

038 "Discretisation of Stochastic Control Problems for Continuous Time Dynamics with Delay" by Markus Fischer and Markus Reiss, August 2005.

039 "What are the Effects of Fiscal Policy Shocks?" by Andrew Mountford and Harald Uhlig, July 2005.

040 "Optimal Sticky Prices under Rational Inattention" by Bartosz Maćkowiak and Mirko Wiederholt, July 2005.

041 "Fixed-Prize Tournaments versus First-Price Auctions in Innovation Contests" by Anja Schöttner, August 2005.

042 "Bank finance versus bond finance: what explains the differences between US and Europe?" by Fiorella De Fiore and Harald Uhlig, August 2005.

043 "On Local Times of Ranked Continuous Semimartingales; Application to Portfolio Generating Functions" by Raouf Ghomrasni, June 2005.

044 "A Software Framework for Data Based Analysis" by Markus Krätzig, August 2005.

045 "Labour Market Dynamics in Germany: Hirings, Separations, and Job-toJob Transitions over the Business Cycle" by Ronald Bachmann, September 2005.

\section{SFB 649, Spandauer Straße 1, D-10178 Berlin http:/ / sfb649.wiwi.hu-berlin.de}

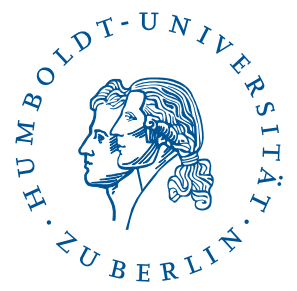


046 "Paternal Uncertainty and the Economics of Mating, Marriage, and Parental Investment in Children" by Dirk Bethmann and Michael Kvasnicka, September 2005.

047 "Estimation and Testing for Varying Coeffcients in Additive Models with Marginal Integration " by Lijian Yang, Byeong U. Park, Lan Xue and Wolfgang Härdle, September 2005.

048 "Zeitarbeit in Deutschland: Trends und Perspektiven" by Michael C. Burda and Michael Kvasnicka, September 2005.

049 "Courtesy and Idleness: Gender Differences in Team Work and Team Competition" by Radosveta Ivanova-Stenzel and Dorothea Kübler, September 2005.

050 "Do Factor Shares Reflect Technology?" by Benjamin Bental and Domonique Demougin, September 2005. 